\title{
Proposal to PV Systems Study
}

\author{
Jordi de la Hoz i Casas \\ Oriol Boix Aragonès
}

\author{
Department of Electrical Engineering \\ E.U.E.T.I.B, Polytechnic University of Catalonia \\ Comte d'Urgell, 187, 08036 Barcelona (Spain) \\ Pone: +34 934137319, fax: +34 934137401, e-mail: Jordi.de.la.Hoz@,upc.edu
}

\begin{abstract}
The Department of Electrical Engineering of the Polytechnic University of Catalonia has been started a new investigation line in the field of renewable energies, concretely in the PV Systems field.

Although our first intention was to study the technical aspects of PV Systems, soon we realized about the scarce PV Systems use. This fact was the reason that motivated us to begin an investigation to determine the principal aspects that impact negatively in the development of the PV Systems.

This article reports on the principal existing barriers in the development of the photovoltaic systems, scans briefly the historical evolution of the existing legislation in the area of renewable energies, and describes the principal symptom of the problem in the development of the photovoltaic systems.
\end{abstract}

Finally the article describes the four principal work points, or investigation lines, that are intended to develop in order to study the PV Systems implementation in Catalonia.

\section{Key words}

PV Systems, PV Systems development barriers, Grid connected.

\section{Introduction. Factors influencing renewable energy deployment}

The development and installation projects of energetic production systems through renewable energies are generally smaller than conventional projects, so its economic conditions, due to incipient industrial and technological moment, are not equivalent. The investment cost in projects of renewable is higher compared to the generated electrical power.

A recent study of the European Union (2) has identified and defined a set of factors that can act as barriers in the development and installation of renewable energies. These factors are defined as political, legislative, financial, fiscal, administrative, technological and informative or educational factors.

\section{A. Political factor}

The lack of political motivation to promote the renewable energies can act as a barrier for its development. Governments and institutions ought to motivate their use. The political will to promote renewable energies affects the legislative, financial, fiscal, administrative, technological, informative and educational factors. Countries that possess this political will have seen increased the use of this kind of energies.

\section{B. Legislative factor}

One of the most important obstacles in the deployment of renewable energies is the lack of accessibility to the electrical market. The producers of electrical energy through systems that use renewable energy sources, special regime producers, need a legislative framework that allows to accomplish their targets. So it is necessary a legislation that guarantee the access to the grid to all the special regime producers, and takes into account the cost disparity between the special regime and the conventional electrical production.

\section{Financial factor}

The high cost of renewable energies makes necessary a public policy of subsidies and low-interest loans. Nevertheless public support should be delivered being conscious that newer technologies due its incipient state, as PV Systems, present higher capital cost building than the others technologies, so public support must be adapted according to each case.

\section{Fiscal factor}

Renewable energy systems compete against conventional energy systems in inequality conditions due to many of current conventional energy systems were built with public financing help, where in many cases the capital cost still has not been returned.

Also it is necessary realize that external cost of electrical energy production in conventional systems are not fully taken into account when the cost of electrical production are calculated. The environmental contribution of renewable energy systems would have to be taken into account in order to obtain greater fiscal benefits.

\section{E. Administrative factor}

Public institutions play a very important role in the development of renewable energies. Public institutions should provide a framework where:

1) Renewable energy systems will not be discriminated.

2) Local legislation will be sensitive to the needs of renewable energy systems, and promote its use.

3) Studies that identify the potential areas to develop renewable energy systems will be promoted. 
4) Information about renewable energy systems will be easily accessible.

\section{F. Technological factor}

The support to the investigation, development and innovation $(\mathrm{I}+\mathrm{D}+\mathrm{I})$ in the renewable energies field is of vital importance to obtain a development and marketing of these new energetic systems on a large scale. This type of helps is especially necessary in technologies, as PV Systems, that are in an incipient development process still.

Also, the use and implementation of these energetic systems by the administration, it has been demonstrated effective. This use acts as inducement in the renewable energy systems development and promotion.

\section{G. Informative and educational factor}

To promote information on the different uses, applications of renewable energy systems is effective for the subsequent development of new facilities, it helps to the acceptance of this type of systems by the public opinion.

\section{Renewable energies legislation evolution}

The political will in the development of renewable energies as alternative to the conventional energy systems has been constant throughout these last years.

This will is based on the need of guaranteeing a smaller energetic external dependency, and to reduce the negative effects of conventional energy systems.

In this paragraph we want to summarize the legislative evolution in the field of renewable energies. For this reason, in the next table, we list those which we believe are the most significant laws promoted during this years. We want to emphasize that such enumeration will be based exclusively on those laws that affect the photovoltaic systems.

Table 1-Summary of Laws that affect to the Photovoltaic Systems

\begin{tabular}{|c|c|c|}
\hline Year & Institution & Law description \\
\hline 1997 & $\begin{array}{c}\text { European } \\
\text { Union }\end{array}$ & $\begin{array}{c}\text { White Paper for a Community } \\
\text { Strategy and Action Plan }\end{array}$ \\
\hline 1997 & Spain & $\begin{array}{c}\text { Law } 54 / 1997 \text { of the electrical } \\
\text { sector }\end{array}$ \\
\hline 1998 & Spain & Royal Decree 2818/1998 \\
\hline 1999 & Spain & $\begin{array}{c}\text { National Plan of Renewable } \\
\text { Energies }\end{array}$ \\
\hline 2000 & Spain & Royal Decree 1663/2000 \\
\hline 2001 & $\begin{array}{c}\text { European } \\
\text { Union }\end{array}$ & $\begin{array}{c}\text { Directive 2001/77/CE } \\
\text { Gov. }\end{array}$ \\
\hline 2001 & $\begin{array}{c}\text { Catalonian } \\
\text { Gecree 352/2001 } \\
\text { Gov. }\end{array}$ & $\begin{array}{c}\text { Catalonian Plan of Renewable } \\
\text { Energies }\end{array}$ \\
\hline 2004 & Spain & Royal Decree 436/2004 \\
\hline
\end{tabular}

In 1997 the European Union fixes as objective for the year 2010 to raise the share of the Renewable Energy Systems. The target was fixed in a $12 \%$. This will was reflected in the book "White Paper for a Community Strategy and Action Plan".

In 1997 is promulgated the law 54/1997 of the electrical sector. In this law the term of "producers of energy through renewable sources", or also calls "producers in the special regime", is defined. Furthermore, the objectives proposed by the European Union in the book "White Paper for a Community Strategy and Action Plan" were collected too.

In 1998 is published the Royal Decree 2818/1998 about electrical energy production by Renewable Energy Systems, and its main objective was to develop the law $54 / 1997$.

In 1999 the National Plan of Renewable Energies was approved as a response to the commitment acquired in the law 54/1997. The objectives of the National Plan of Renewable for the photovoltaic systems can be observed in the following table.

Table-2. Objectives of the National Plan of Renewable Energies in the photovoltaic systems field

\begin{tabular}{|c|c|}
\hline \multicolumn{2}{|c|}{ Objectives of the National Plan for the year 2010 } \\
\hline Systems & Installed Power [MW] \\
\hline Stand alone PV Systems & 30 \\
\hline $\begin{array}{c}\text { Grid Connected PV } \\
\text { Systems }\end{array}$ & 115 \\
\hline Total Installed Power & 145 \\
\hline
\end{tabular}

In September of 2000 , by means of the Real Decree $1663 / 2000$, were simplified the grid connection conditions for the PV Systems.

In the year 2001 the European Union approved the directive 2001/77/CE related to the promotion of electricity generated by renewable energy systems in the European market of electricity.

In the year 2001 the Catalan government approves the Decree 352/2001 where the necessary administrative actions to construct and exploit a grid connected PV System were simplified. In the same year the Catalonian government approves to the Catalonian Plan of Renewable Energies, where are defined the new strategic priorities that will guide the political and technical action of the Catalan administration

In the year 2004 the Royal Decree 436/2004 is approved. The Royal Decree 436/2004 establishes the methodology for the update and systematizing the legal and economic regime of the renewable energies systems, and wants to be a lasting economic framework for the special regime. 


\section{Problem definition}

To determine what we consider is a symptom of a problem in the grid connected PV Systems development, we have used the data of the National Commission of Energy, in the period 1990 to 2002.

We have concentrated our attention in the results of the report related to the grid connected PV Systems. By means of the report's results we can observe that it has risen the number of grid connected PV Systems, and the electric energy fed into the grid.

According to the report of the National Commission of Energy the increase is due to auspicious framework that introduces the Royal Decree 2818/1998, and to the simplification of the administrative proceedings.



Figure-1. Number of grid connected PV Systems evolution

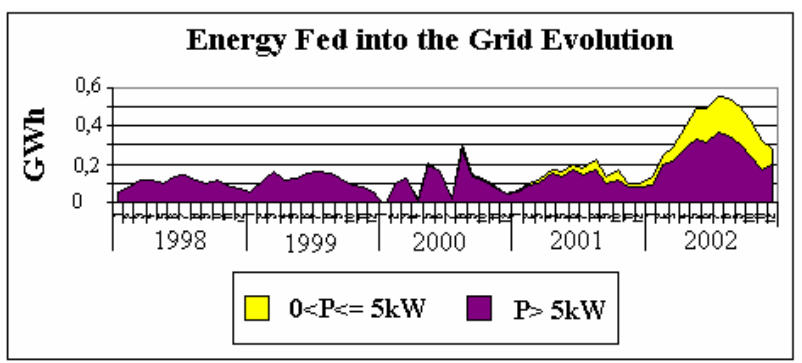

Figure-2. Energy fed into the grid by PV Systems

Nevertheless, although exists a growth trend in the total generating capacity, this growth is not sufficient to achieve the objectives proposed in the National Plan of Renewable Energy. In figure-3 we can see that it would be necessary an annual increase of $13 \mathrm{MW}$ to reach the goal proposed by the National Plan of Renewable Energy.

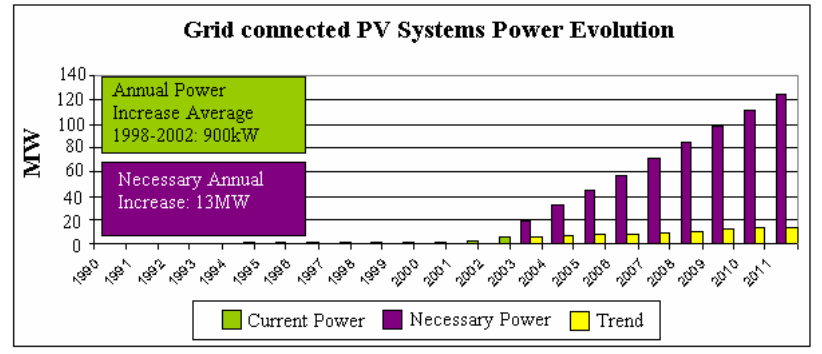

Figure-3.Grid connected PV Systems power evolution
We will end this paragraph describing three possible hypotheses that could explain the difference between the goals of the National Plan of Renewable Energy and the obtained real data:

\section{A. $\quad$ First hypothesis}

The accomplished actions in the political, legal, administrative, financial, fiscal, administrative, technological, informative and the educational field have not been sufficient or correct to promote the PV Systems.

\section{B. Second hypothesis}

The targets of the National Plan of Renewable Energy are too ambitious.

\section{C. $\quad$ Third hypothesis}

The disagreement between the obtained real data and the objectives of the National Plan of Renewable Energy is due to a set formed by the first and second hypothesis.

\section{Investigation line}

We propose an investigation line routed to determine how established grid connected PV Systems are at the present moment in Catalonia, their possible generalized development, and the factors that affect the PV Systems development. The investigation line will be composed by four principal work points:

\section{A. First work point: to determine how established PV} Systems are at the moment in Catalonia

Examples of the actions that are intended to accomplish in this point are to determine:

5) The number and the power of the grid connected PV Systems

6) The profile of the owners of the grid connected PV Systems

7) The more usual technical solutions

B. Second work point: to study and to determine the factors that affect the grid connected PV System development

Examples of the actions that are intended to accomplish in this point are:

8) To determine the satisfaction degree of the PV Systems' owners

9) To identify the main problems, technical, legal, administrative,... of the grid connected PV Systems

C. Third work point: to study grid connected PV Systems development viability

Some of the actions to accomplish are:

10) To identify and to locate the potential grid connected PV Systems facilities

11) To quantify the necessary investment

12) To quantify economically the environmental benefits

D. Fourth work point: to determine the necessary measures for grid connected PV Systems development in Catalonia 


\section{Conclusion}

Exist in Catalonia, and Spain, a political will to develop the renewable energies systems, an example of this political will is the legal framework that these systems possess. Nevertheless, the grid connected PV Systems development is highly insufficient. According to the current PV Systems power evolution trends, the objectives of the National Plan of Renewable Energies will not be reach.

We are conscious about all the work done by the institutions, but sincerely we believe that these actions are not enough for a real grid connected PV Systems promotion. So we have started a new investigation line in order to know the real barrier factors in the grid connected PV Systems implementation in Catalonia, as a tool to promote them.

The investigation line is composed by four work points, and it wants to be a modest contribution routed to determine the necessary measures for grid connected PV Systems development in Catalonia

\section{References}

[1] Jordi de la Hoz i Casas (2004).”Aportación al estudio de la implantación y desarrollo de la energía solar fotovoltaica en Cataluña". Proyecto de Tesis. Universidad Politécnica de Cataluña. Barcelona, Julio de 2004.

[2] EUROPEAN ENVIRONMENT AGENCY. "Renewable energies: success stories". Environmental issue report. EEA, Cophenhagen, 2001.

[3] COMISIÓN NACIONAL DE ENERGÍA.'Informe sobre las compras de energía al Régimen Especial. Período: Año 2002". Madrid 2003.

[4] Wiser, R. H. [et al] "Financing investments in renewable energy: the impacts of policy design". Renewable and Sustainable Energy Reviews 2 (1998) 361-386.

[5] Sardar, M. [et al] "Sustainable economic developments in the Australian Energy Sector: finding of the Australian Energy Planning System Optimization Model". Renewable and Sustainable Energy Reviews, Vol. 1, No. 3, pp. 229-238, 1997.

[6]Wiser, R. H. "The role of public policy in emerging green power markets: an analysis of marketer preferences".

Renewable and Sustainable Energy Reviews 4 (2000) 172-212.

[7] INTERNATIONAL ENERGY AGENCY. "Photovoltaic Power Systems Programme. Annual report 2003”. s.a. 2003. 